\title{
Perancangan Media Sosialisasi Sistem Informasi Akademik Satya Wacana Berbasis Video Infografis
}

\author{
Dian Mei Tiasih"*, Michael Bezaleel Wenas² ${ }^{2}$ iD \\ ${ }^{12}$ Program Studi Desain Komunikasi Visual - FTI UKSW Salatiga, Jawa Tengah, Indonesia \\ *Corresponding author:692014801@student.uksw.edu
}

\begin{abstract}
Kurangnya media sosialisasi yang komunikatif dan dinamis, yang dapat digunakan untuk menyampaikan informasi akademik satya wacana (SIASAT), sehingga mahasiswa kesulitan dalam mendapatkan informasi dengan cepat. Tujuan penelitian ini adalah untuk mengembangkan media sosialisasi sistem informasi akademik satya wacana berbasis video infografis. Penelitian ini menggunakan metode deskriptif kualitatif. Tahapan penelitian ini menggunakan strategi linear yang meliputi empat tahapan yaitu pengumpulan data, analisis data, perancangan media, dan pengujian. Pengumpulan data dilakukan menggunakan metode observasi, wawancara, serta dokumentasi. Hasil penelitian adalah pada tahap pengujian didapatkan bahwa video infografis sosialisasi SIASAT memiliki komponen konten cukup lengkap dan alurnya cukup jelas. Desain dan pewarnaan tiap komponen sudah baik dan menarik. Selain itu penggunaan audio untuk backsound sudah tepat sehingga mendukung pengisi suara menjadi cukup jelas dan enak didengar. Pengujian kepada mahasiswa diperoleh hasil bahwa video infografis sosialisasi SIASAT mudah dimengerti dan bermanfaat sehingga mahasiswa lebih paham dalam menggunakan SIASAT, serta pengunaan ilustrasi dan pengisi suara tidak membosankan untuk dinikmati sampai video selesai ditayangkan. Sehingga dapat disimpulkan bahwa media sosialisasi sistem informasi akademik satya wacana berbasis video infografis layak dan dapat digunakan untuk menyampaikan informasi akademik satya wacana (SIASAT).
\end{abstract}

Keywords: akademik; infografis; sistem; sosialisasi; video.

\begin{tabular}{|c|c|c|}
\hline History: & & Publisher: Undiksha Press \\
\hline Received & : 4 Mei 2020 & Licensed: This work is licensed under \\
\hline Revised & $: 5$ June 2020 & a Creative Commons Attribution 3.0 License \\
\hline Accepted & : 26 July 2020 & (c) (7) (?) \\
\hline
\end{tabular}

\section{Introduction}

Sosialisasi adalah suatu proses yang dapat memberikan nilai dalam upaya menyelaraskan hidup ditengah masyarakat sehingga terjadi pembentukan sikap dan kepribadian (Anwar \& Nurkidam, 2018; Hadi, 2017). Mahasiswa baru (MABA) merupakan civitas akademik yang baru memasuki lingkungan di Universitas (Al-Kariimah \& Rosiana, 2017; Iflah \& Listyasari, 2013). Dalam sosialisasi berdasarkan perencanaan, dari semua tujuan pembelajaran, proses, materi dan penilaian telah dikonstruksi secara matang, maka semuanya terukur, dapat dievaluasi dan dapat dimonitor (Damsar, 2011). Pada tiap tahun ajaran baru, sebuah informasi akademik dalam sistem, tentu akan banyak membantu MABA dalam mengikuti aktivitas dalam studinya, diantaranya informasi pengambilan matakuliah dalam tiap semester yang harus ditempuh, biaya per semester yang harus dikeluarkan dan informasi akademik lainnya yang tentu akan sangat membantu MABA dalam studi di Universitas.Dalam tiap tahun ajaran baru, Univeristas Kristen Satya Wacana (UKSW) mempunyai kegiatan yang disebut Orientasi Mahasiswa Baru (OMB), dimana didalamnya terdapat agenda sosialisasi SIASAT kepada MABA yang wajib diketahui dan digunakan oleh civitas UKSW. SIASAT adalah Sistem Informasi Akademik Satya Wacana yang terintegrasi 
dengan beberapa sistem yang ada di UKSW, baik dengan perpustakaan, keuangan dan administrasi akademik lainnya, sedangkan sistem informasi yang ada di keuangan dan perpustakaan tidak saling terintegrasi, pun sebaliknya sistem informasi yang ada dapat saling terintegrasi melalui SIASAT, karena di dalam SIASAT mahasiswa dapat mengelola secara mandiri kegiatan perkuliahannya di UKSW.

Berdasarkan hasil observasi dan wawancara, ditemukan permasalahan yang terjadi saat ini di Univeristas Kristen Satya Wacana (UKSW) yaitu sosialisasi SIASAT pada kegiatan OMB masih berupa tulisan pada buku panduan OMB yang dibagikan pada MABA dan file berupa dokumentasi .pdf dan ppt. yang digunakan untuk dipresentasikan di dalam kelas dalam agenda OMB. Sosialisasi yang hanya menggunakan tulisan menjadi kurang menarik sehingga siswa tidak memahami persyaratan dalam berkuliah di UKSW. SIASAT merupakan sistem yang wajib digunakan oleh mahasiswa dan menjadi kewajiban bagi univeristas untuk menyampaikan secara menyeluruh SIASAT yang digunakan mahasiswa, namun prosedur atau tahapan dalam melakukan SIASAT seperti registrasi matakuliah atau syarat berkuliah masih belum disampaikan dengan baik mengingat keterbatasan waktu dalam menyampaikan SIASAT kepada MABA dalam OMB, seperti proses pendaftaran matakuliah, kartu studi, hasil studi, jadwal kuliah, transkrip nilai, tagihan, keaktifan mahasiswa yang ditempuh dalam semester tertentu, belum dengan baik tersampaikan. Kepala Bagian Administrasi dan Regristrasi Akademik (BARA) yang ikut terlibat langsung dalam penyelenggaraan sosialisasi SIASAT pada agenda OMB mengatakan, sosialisasi SIASAT dalam agenda OMB dirasa penyampaian masih kurang menyeluruh karena hanya dapat tersampaikan SIASAT mahasiswa untuk registrasi matakuliah saja, harapan agar kedepannya MABA bisa menggali informasi perkuliahan dengan baik melalui buku panduan yang sudah ada, sehingga MABA tidak perlu bertanya-tanya kembali langkah-langkah dalam menggunakan SIASAT yang ada, mengingat SIASAT adalah sistem yang wajib digunakan oleh civitas. Beberapa MABA mengatakan, sosialisasi disaat agenda OMB, MABA dibantu oleh kakak fasilitator dan sosialisasi SIASAT pada saat OMB sangat membantu mereka melakukan regristrasi matakuliah saja, akan tetapi untuk mengerti dan memahami prosedur tahapan administrasi akademik dalam SIASAT mereka belum paham dan juga karena informasi dari buku panduan dirasa kurang menarik dan membosankan, sehingga mereka masih harus bertanya kepada kakak angkatan yang menjadi fasilitator selama mereka menjadi MABA, seperti saat akan melakukan tagihan perkuliahan, melihat transkrip nilai, melakukan SIASAT pada semester berikutnya, adjustment matakuliah yang dapat diambil, hingga poin keaktifan, mereka masih perlu dibimbing fasilitator untuk melakukan tahapan dalam melakukan SIASAT agar mereka dapat mengikuti perkuliahan dalam satu semester tertentu.

Salah satu solusi untuk mengatasi permasalahan tersebut adalah dengan memanfaatkan teknologi dalam menyalurkan informasi. Pemanfaatan teknologi informasi dan komunikasi pada bidang layanan administrasi akademik menjadi suatu kebutuhan, bukan hanya sekedar prestige atau lifestyle manajemen pendidikan modern (Idrus, 2014; Indrayani, 2011). Oleh karena itu, informasi menjadi bagian yang sangat penting untuk mendukung proses kegiatan belajar, kerja administrasi dan sosialisasi pelaksanaan sistem yang ada. Bentuk penyajianpun tentu saja mengikuti perkembangan teknologi saat ini yang memanfaatkan berbagai elemen dari teknologi informasi dan komunikasi. Sosialisasi melalui media komunikasi sangatlah penting, sehingga informasi yang ingin disampaikan dapat diterima oleh civitas dengan baik dan media tersebut dapat diakses kapan saja dan dimana saja. Terutama untuk mengenalkan sistem yang dimiliki UKSW yang bersifat wajib digunakan oleh civitas. Dengan kekuatan visual yang menarik agar mudah dipahami dan dapat menjadi sumber informasi visual atau data bergambar (Syaripul \& Bachtiar, 2016; Wicandra, 2001). Berdasarkan kebutuhan akan informasi yang diperlukan MABA dan ketersediaan sistem yang terintegrasi di UKSW, dibutuhkan sebuah sosialisasi melalui media 
informasi yang mendukung pada fakta-fakta yang ingin disampaikan dan menjawab kebutuhan MABA serta sebagai media alternatif dalam menyampaikan satu sistem administrasi akademik dalam SIASAT, secara tepat, menyeluruh dan informasinya menarik bagi MABA, diperlukan pembuatan media sosialisasi yaitu berupa media video infografis SIASAT UKSW, dalam perancangannya menggunakan infografis yang merupakan kombinasi informasi untuk menjelaskan cerita yang tidak dapat diceritakan oleh teks dan foto yang dikemas dalam bentuk visual (Tufte, 1990).

SIASAT adalah Sistem Informasi Akademik Satya Wacana yang dibuat untuk membantu mahasiswa dalam melakukan kegiatan administrasi akademik yang bersifat wajib. Di dalam melakukan SIASAT, khususnya SIASAT mahasiswa, terdapat prosedur yang wajib dilakukan oleh mahasiswa melalui skema kegiatan admisistrasi akademik dalam 1 semester, diantaranya: (1) mahasiswa wajib memeriksa tagihan secara mandiri tiap semester, (2) mahasiswa wajib melakukan pembayaran uang kuliah awal semester, (3) mahasiswa yang akan melanjutkan studi pada semester berikutnya, wajib melakukan registrasi ulang, (4) mahasiswa wajib melakukan perwalian, (5) mahasiswa yang telah melakukan registrasi mahasiswa (rm) dan melakukan perwalian wajib mengakses siasat dengan alamat http://siasat.uksw.edu, (6) Mahasiswa dapat beraktifitas mengikuti perkuliahan setelah melakukan pembayaran awal semester perkuliahan dan melakukan SIASAT. (7) Pelunasan wajib dilakukan mahasiswa di tiap pertengahan semester, dapat secara langsung membayar melalui loket BAK ataupun melalui e-banking, (8) Mahasiswa melakukan Tes Akhir Semester (TAS) untuk memperoleh nilai akhir semester, (9) Mahasiswa berhak mendapatkan nilai dari masing-masing dosen pengampu MK dengan wajib mengisi formulir evaluasi dosen yang mengapu MK. Skema kegiatan admisistrasi akademik akan berjalan kembali selama mahasiswa yang bersangkutan masih aktif dalam aktifitasnya menjadi mahasiswa UKSW. Sistem informasi akademik ini memerlukan media yang dapat memberikan informasi secara menarik. Salah satunya adalah media video grafis.

Media sebagai bentuk perantara yang digunakan oleh manusia untuk menyampaikan atau menyebar ide, gagasan, atau pendapat sehingga ide, gagasan atau pendapat yang dikemukakan itu sampai pada penerima yang dituju (Arifuddin, Suwatra, \& Mahadewi, 2020; Arsyad, 2014). Semua jenis media massa tidak secara langsung bertujuan untuk mengajari masyarakat. Akan tetapi, siaran berita, film, iklan, pertunjukan seni budaya, sampai dengan informasi ilmiah, berdampak sangat besar bagi perilaku warga masyarakat. Manusia tidak mungkin mengadakan sosialisasi tanpa melibatkan pihak atau unsur dari luar. Unsur dari luar itulah yang disebut media sosialisasi. Media sosialisasi adalah pihak-pihak yang menjadi perantara terjadinya sosialisasi (Suhardi, Sunarti, 2009). Dalam dunia pendidikan, video merupakan sarana yang paling tepat dan sangat akurat dalam menyampaikan pesan dalam bentuk audio-visual (Tegeh, Simamora, \& Dwipayana, 2019; Yuliani, Antara, \& Magta, 2017). Video akan sangat membantu pemahaman siswa dalam meniru, mengikuti, mencontoh dan memahami urutan tindakan yang harus dikuasai suatu mata pelajaran. Terlebih lagi untuk mata pelajaran praktek, hal ini akan sangat membantu siswa dalam cara memegang peralatan praktek, urutan pengoperasian dan perawatan setelah penggunaan. Keuntungan dari media video antara lain: ukuran tampilan video sangat fleksibel dan dapat diatur sesuai kebutuhan, video merupakan bahan ajar non cetak yang kaya informasi dan lugas karena dapat sampai kehadapan siswa secara langsung, dan video menambah suatu dimensi baru terhadap pembelajaran (Daryanto, 2011; Yusnia, 2019). Infografis adalah suatu cara baru dalam penyampaian informasi yang cukup efektif modern ini. Infografis merubah data-data teks menjadi mudah dimengerti lewat berbagai teknik visualisasi data yang menarik. Infografis membantu publik luas untuk memahami konsep-konsep yang kompleks dengan lebih mudah dan cepat. Infografis adalah informasi yang disajikan dalam bentuk grafis. Infografis atau grafis informasi merupakan isyarat - isyarat visual untuk mengkomunikasikan informasi. 
Infografis tidak perlu mengandung jumlah data tertentu, memiliki kompleksitas tertentu, atau menyajikan tingkat analisis tertentu. Tidak ada ambang batas bagi sesuatu untuk 'menjadi' sebuah infografis. Infografis bisa sesederhana sebuah rambu lalu-lintas dengan gambar orang memegang sekop yang memberitahukan bahwa di depan ada kegiatan konstruksi, atau serumit visual untuk perekonomian global (Lankow, Ritchie, \& Crooks, 2014). Informasi menjadi kebutuhan mutlak bagi setiap orang, terlebih bagi civitas akademik yang baru memasuki sebuah Universitas, dan hampir pada kegiatan belajar mengajar yang ada, pada dasarnya membutuhkan informasi yang komunikatif. Media video infografis sendiri memiliki beberapa keunggulan, diantaranya adalah penerapan gaya flat design yang dikombinasikan dengan animasi ilustrasi dan elemen infografis dan sesuai dengan target primer yang merupakan pelajar dan mahasiswa, durasi video infografis relatif singkat.

Penelitian yang dilakukan oleh Cahyadi, Budiardjo, \& Dewanto (2016) menunjukan bahwa Infografis akan lebih mudah menarik minat masyarakat. Hal ini dikarenakan sebuah data dan informasi yang ingin disampaikan telah ditambah dengan nilai estetis sebuah karya visual sehingga karya visual tersebut dapat dinikmati dan dicerna oleh pembaca karena berdasarkan pada fakta-fakta yang ingin disampaikan. Penelitian yang dilakukan oleh Siddiq, Sudarma, \& Simamora (2020) menyatakan media infografis berupa animasi 2D yaitu Video Animasi Infographic dapat memberikan bentuk informasi menarik, efektif, serta mudah diterima khususnya oleh siswa. Penelitian tersebut menunjukkan bahwa penggunaan media infografis lebih mudah menarik minat dan mudah dipahami serta memiliki keunikan tersendiri dalam menyampaikan sebuah informasi berdasarkan pada fakta-fakta yang ingin disampaikan dalam bentuk karya visual.

Tujuan penelitian ini adalah untuk mengembangkan media sosialisasi sistem informasi akademik satya wacana berbasis video infografis. Penelitian ini memiliki perbedaan dengan penelitian sebelumnya yaitu pada penelitian ini dikembangkan media sosialisasi berbasis video infografis yang dipergunakan untuk memberikan informasi SIASAT. Pengembangan media sosialiasi berbasis video grafis ini diharapkan dapat membantu memberikan informasi SIASAT dengan cepat dan mudah dipahami oleh mahasiswa.

\section{Materials and Methods}

Metode yang digunakan dalam penelitian ini adalah menggunakan metode kualitatif. Di dalam penelitian kualitatif terdapat metode penelitian deskriptif yang menjelaskan bahwa penelitian deskriptif adalah suatu bentuk penelitian yang ditujukan untuk mendeskripsikan fenomena-fenomena yang ada, baik fenomena alamiah maupun fenomena buatan manusia. Penggunaan hipotesis dalam penelitian deskriptif bukan dimaksudkan untuk diuji melainkan bagaimana berusaha menemukan sesuatu yang berarti sebagai alternatif dalam mengatasi masalah penelitian melalui prosedur ilmiah. Penelitian deskriptif tidak hanya terbatas pada masalah pengumpulan dan penyusunan data, tapi juga meliputi analisis dan interpretasi tentang arti data tersebut. Dalam melakukan penelitian ini metode penelitian kualitatif bersifat deskriptif digunakan sebagai salah satu metodenya karena karakteristik prosedur administrasi akademik dalam SIASAT yang sudah ada dalam buku panduan administrasi akademik dapat digunakan sebagai acuan dalam perancangan media video infografis di dalam mensosialisasikan panduan SIASAT yang baru.

Pengumpulan data dilakukan menggunakan metode observasi, wawancara, serta dokumentasi. Strategi yang digunakan dalam penelitian ini adalah strategi linear dimana strategi linear menerapkan urutan logis pada tahapan perancangan yang sederhana dan relatif sudah dipahami komponennya (Sarwono, 2007). Adapun tahapan-tahapan yang digunakan dapat dilihat pada Gambar 1 : 


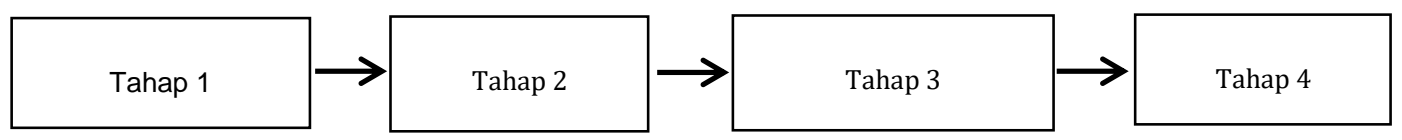

Gambar 1. Tahap Penelitian Strategi Linear

Langkah pertama pada yang dilakukan adalah pengumpulan data informasi, tahap selanjutnya analisis data, tahap ketiga adalah perancanga media, dan tahap terakhir adalah pengujian.

\section{Results and Discussion}

Berdasarkan hasil wawancara dengan BAA yaitu media informasi yang digunakan dalam sosialisasi SIASAT pada MABA masih berupa buku materi OMB dan file presentasi yang berupa .ppt atau .pdf. Media sosialisasi tersebut, hanya mengakomodasi SIASAT untuk registrasi matakuliah diawal perkuliahan MABA, namun prosedur atau tahapan administrasi akademik dalam melakukan regristrasi matakuliah atau syarat berkuliah masih belum disampaikan dengan baik mengingat keterbatasan waktu dalam menyampaikan SIASAT kepada MABA, seperti proses pendaftaran matakuliah, kartu studi, hasil studi, jadwal kuliah, transkrip nilai, tagihan, keaktifan mahasiswa yang ditempuh dalam semester tertentu, belum dengan baik tersampaikan, sedangkan SIASAT merupakan sistem yang wajib untuk diketahui dan digunakan civitas UKSW. Hasil wawancara dengan BARA diperoleh data informasi dari buku panduan administrasi akademik yang dapat menggali informasi administrasi perkuliahan dengan baik, sehingga harapannya mahasiswa tidak perlu bertanya-tanya kembali langkah-langkah untuk melakukan kegiatan administrasi akademik dalam registrasi dan persyaratan berkuliah dalam menggunakan SIASAT yang ada. Data yang diperoleh digunakan sebagai pertimbangan pembuatan skenario alur video infografis. Hasil wawancara dengan MABA bertujuan untuk mengetahui tanggapan terhadap media sosialisasi SIASAT yang sudah ada. Hasil yang diperoleh berupa data yang menunjukan bahwa MABA mengalami kesulitan untuk memahami prosedur tahapan SIASAT karena informasi dari buku panduan dirasa terlalu banyak tulisan yang membosankan dan kurang menarik, sehingga mereka masih harus bertanya kepada kakak angkatan yang menjadi fasilitator selama mereka menjadi MABA.

Tahap pertama yang dilakukan sebagai langkah awal adalah dengan mengumpulkan data informasi sesuai sumber terkait. Data dicatat dan didokumentasikan oleh peneliti melalui observasi yang dilakukan dengan pengamatan langsung terhadap objek yaitu dengan mengikuti kegiatan Orientasi Mahasiswa Baru tahun 2017-2018 untuk melihat dan mengamati fenomena dan kegiatan yang terjadi dalam rangka sosialisasi SIASAT kepada MABA UKSW. Kemudian melakukan wawancara dengan manager Biro Administrasi Akademik (BAA) periode 2014-2017 dan Kepala Bagian Administrasi dan Regristrasi Akademik (BARA) periode 2014-2017, serta melakukan wawancara dengan MABA UKSW. Tujuan wawancara adalah untuk mengetahui permasalahan media informasi SIASAT di UKSW.

Tahap kedua merupakan tahap analisis data. Analisis data dilakukan berdasarkan dengan data wawancara yang telah dikumpulkan. Setiap data dianalisa sehingga diperoleh sebuah pengembangan ide untuk menentukan karakteristik dan fitur yang dibutuhkan sehingga menghasilkan sebuah media informasi untuk sosialisasi berupa video infografis yang tepat kepada MABA. Hasil analisis yang didapat yaitu, karakteristik media sosialisasi berupa video infografis yang dikemas secara singkat, jelas dengan alur cerita yang baik, menarik berdasarkan pada fakta-fakta yang ingin disampaikan dan mudah dipahami MABA, dimana video infografis yang dikemas dengan baik dan efektif mampu mendukung media sosialisasi sebelumnya yang berupa buku materi OMB dan file presentasi. 
Tahap ketiga merupakan tahap perancangan media. Pada penelitian ini diperlukan tahapan dalam merancang desain untuk dapat membentuk karakter dari video infografis animasi 2 dimensi, tentu melalui proses tahap pembuatan atau yang sering dikenal dengan proses produksi animasi (Suyanto, 2006). Adapun proses tahapan sebagai berikut praproduksi, produksi, dan pasca produksi yang sesuai dengan kebutuhan media sosialisasi SIASAT berbasis video infografis seperti pada Gambar 2.

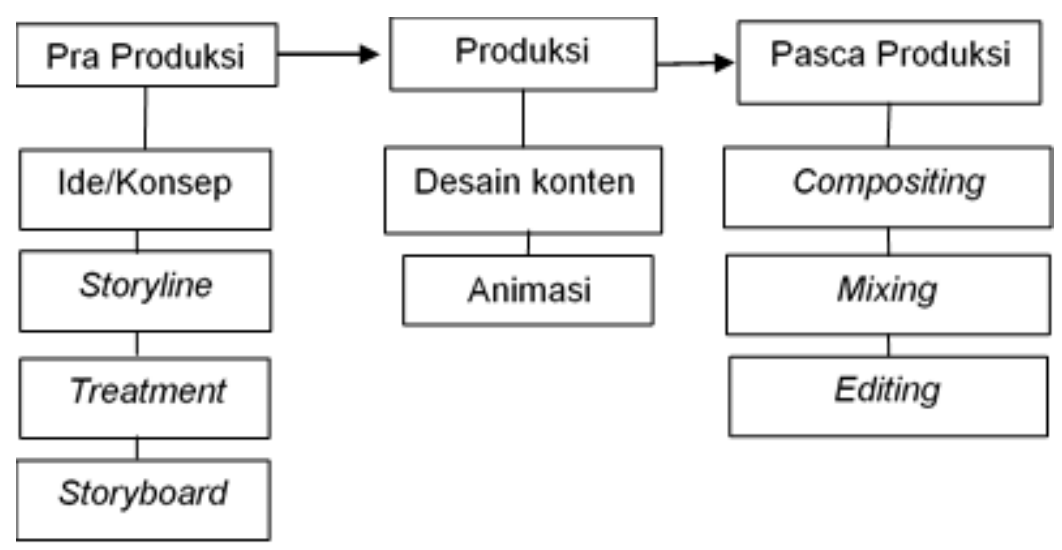

Gambar 2. Bagan Metode Perancangan

Proses pertama yaitu proses pra-produksi adalah menentukan ide cerita, merancang konsep, membuat skenario alur video dan pembuatan storyboard. Pada perancangan media diawali proses dengan membuat ide/konsep. Konsep perancangan video adalah menjelaskan tentang sistem administrasi akademik UKSW melalui sebuah alur cerita dengan dikemas secara sederhana dan informatif yang mudah dipahami oleh MABA. Setelah konsep sudah terbentuk dilajutkan dengan pembuatan storyline, treatment dan storyboard. Storyline merupakan kajian yang dirangkai menjadi cerita yang menarik dan merupakan ringkasan atau garis besar alur cerita yang menggambarkan isi dari suatu film atau pementasan yang dilakukan secara umum. Storyline dirancang berdasarkan ide cerita yang sudah direncanakan. Kepala BARA mengusulkan bahwa penyusunan storyline sebaiknya dimulai dengan pengenalan secara umum tentang skema kegiatan administrasi akademik semester dan alur diagram regristrasi mahasiswa kemudian informasi langkah-langkah dalam menggunakan SIASAT hingga mahasiswa dapat beraktivitas dalam perkuliahan. Dengan mengetahui prosedur yang berurutan, diharapkan MABA dapat mengerti dan memahami sehingga dalam pelaksanaan berSIASAT, mahasiswa dapat dengan mandiri melakukannya. Pada bagian akhir video, mengajak audience hendaknya menjadi mahasiswa yang aktif dan mandiri. Tahap selanjutnya yaitu treatment. Treatment merupakan sketsa dari sebuah skenario dan menjadi kerangka cerita (Widagdo \& Gora, 2007). Treatment disusun berdasarkan hasil riset awal, baik langsung maupun tak langsung dan berdasarkan rumusan ide dalam bentuk film statement yang diuraikan secara deskriptif tentang bagaimana rangkaian mengenai media sosialisasi SIASAT dengan video infografis. Storyboard adalah sketsa gambar yang disusun berurutan sesuai dengan naskah sehingga menghasilkan persepsi yang sama pada ide cerita.

Dalam perancangan media sosialisasi SIASAT dengan video infografis ini storyboard digunakan sebagai acuan dalam pembuatan video di setiap adegan. Perancangan storyboard dapat dilihat pada Gambar 3 . 


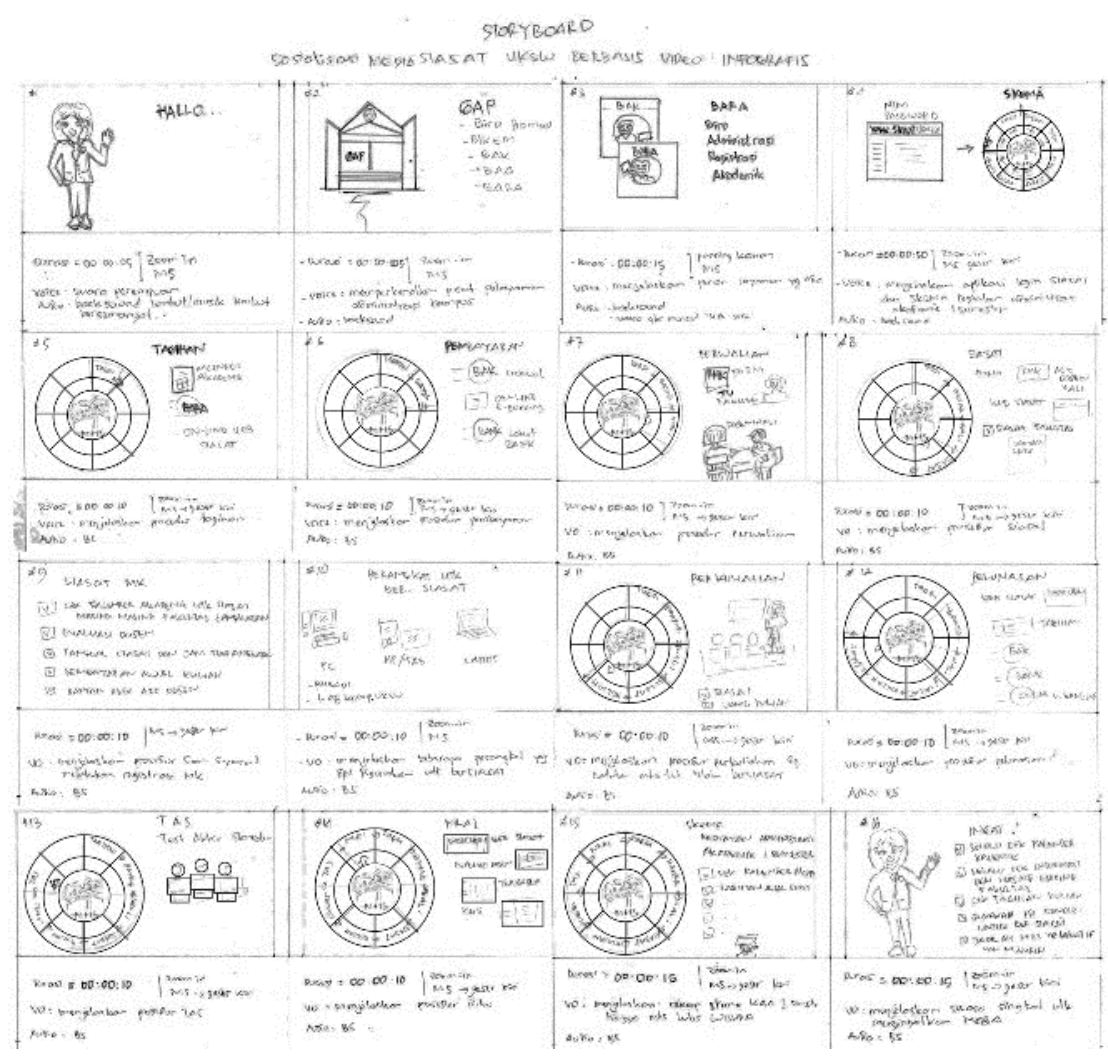

Gambar 3. Storyboard

Storyboard yang telah dibuat bisa saja terjadi perubahan dalam tampilan maupun isinya. Hal tersebut dapat terjadi apabila saat pengujian video, para audience menginginkan adanya perubahan atau penambahan pada video. Kemudian pada tahap produksi yaitu desain konten, pada tahap ini dilakukan proses desain dengan menggunakan software grafis dengan mengikuti konsep seperti pada storyline dan storyboard. Konten karakter mengambil sosok perempuan yang mewakili dan mencirikan sebagai fasilitator MABA yang menggunakan jas almamater UKSW, ini didapat dari hasil wawancara dengan MABA untuk mendapatkan daya tarik penyampai sosialisasi SIASAT pertama di dalam OMB yang dapat mengambarkan mahasiswa UKSW yang berkarakter memiliki pesan emosional yang positif, ceria, dapat memberikan informasi yang berkesan dinamis dan luwes. Peneliti juga mendapatkan masukan dari Bapak Happie Prasetyo dari Biro Teknologi dan Sistem Informasi (BTSI) sebagai perancang buku Panduan Administrasi Akademik UKSW untuk konten Skema Kegiatan Administrasi Akademik 1 Semester. Warna konten sebagian besar menggunakan warna cerah agar bekerja dengan baik pada latar belakang yang terang maupun gelap, menciptakan kontras dan menarik audience. Perancangan konten dapat dilihat pada Gambar 4. 


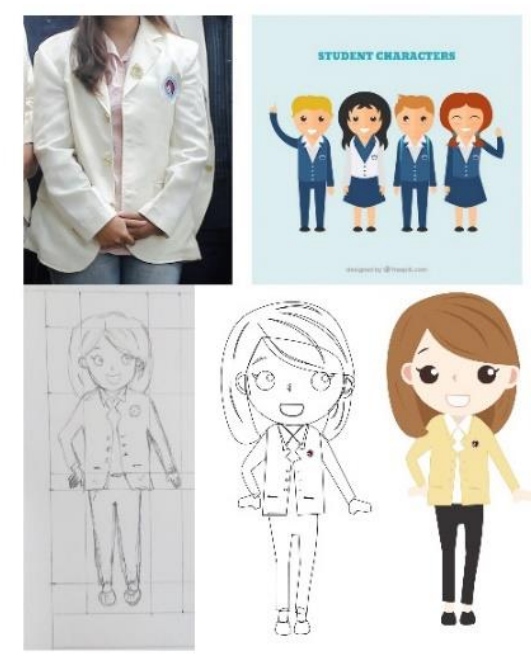

Gambar 4. Perancangan karakter

Tahap selanjutnya dalam produksi adalah animasi untuk menggerakan konten yang disusun per scene. Pembuatan animasi pada awalnya dikerjakan dengan membuat sketsa gambar yang kemudian digerakkan satu demi satu, hingga suatu gambar objek dapat bergerak Munir (2013). Dalam proses ini dilakukan penambahan efek-efek seperti efek transisi, warna, efek gerak, dan efek-efek lainnya sesuai dengan kebutuhan. Perancangan animasi dapat dilihat pada Gambar 5.

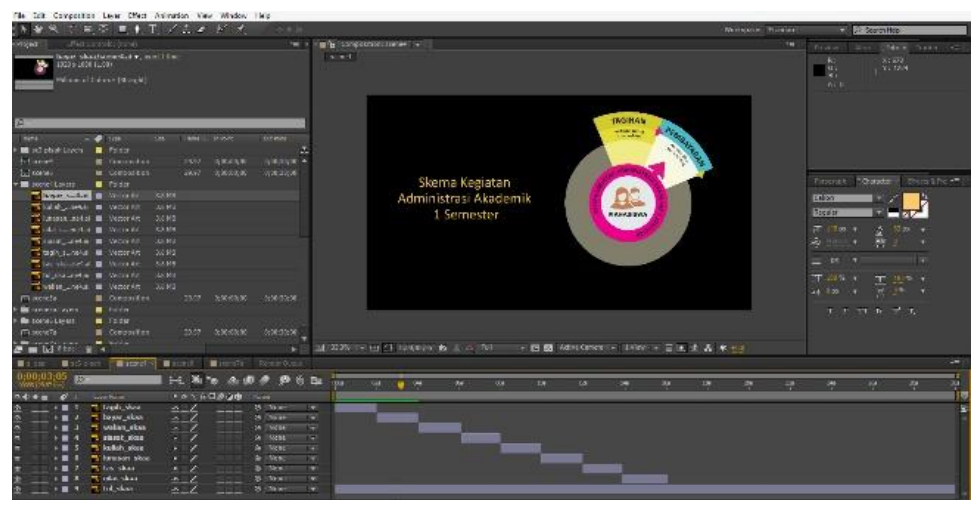

Gambar 5. Perancangan animasi

Tahapan berikutnya dalam produksi adalah animasi untuk pergerakan icon fasilitator yang dibuat berjalan dari samping lalu pergerakan kamera zooming untuk menimbulkan kesan tegas dan focus. Arimbawa, Agustini, \& Santyadiputra (2018) dalam penelitiannya mengatakan animasi mampu menampilkan animasi dalam 2 dimensi dan juga bisa dijadikan sebagai media untuk penyampaian informasi menjadi lebih menarik. Animasi yang dikembangkan dapat dilihat pada Gambar 6.

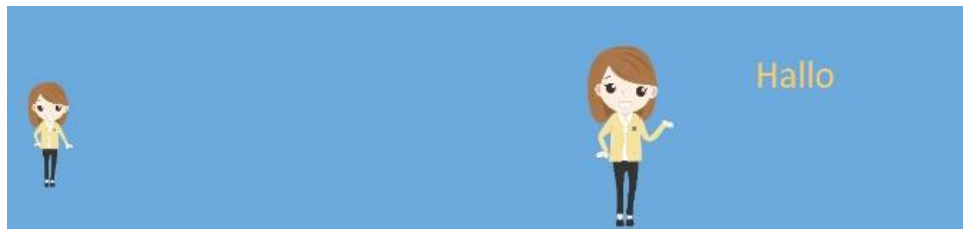

Gambar 6. Animasi 
Setelah melakukan tahapan animasi dalam produksi adalah tahap pasca pruduksi yang dibagi menjadi 3 bagian, pertama adalah compositing yaitu proses digital dalam menggabungkan beberapa gambar atau beberapa urutan gambar menjadi satu bagian film atau rekaman digital, dapat dilihat pada Gambar 7.

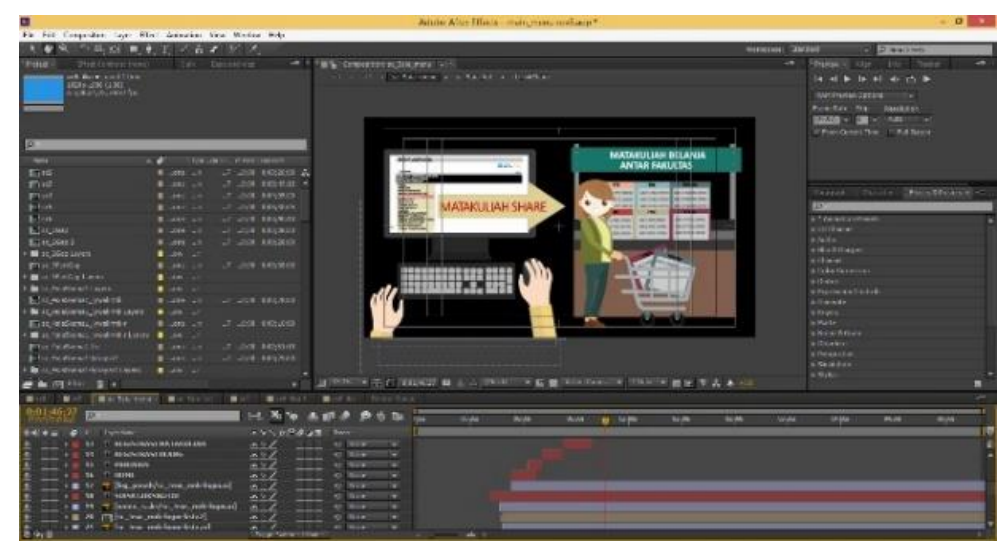

Gambar 7. Compositing

Berikutnya adalah mixing, yang dilakukan dengan merekam voice over (vo) untuk mengisi suara dalam menyampaikan informasi untuk sosialisasi SIASAT dilakukan di dalam studio audio dengan mixing audio sebagai mastering vo. Mixing audio adalah membersihkan noise pada suara narasi dan memberikan efek pada animasi transisi Iskandar \& Tumimomor, (2017). Tata Suara memainkan peranan penting dalam sebuah film, tata suara erat kaitannya dengan pengaturan penguatan suara agar bisa terdengar kencang tanpa mengabaikan kualitas dari suara-suara yang dikuatkan. Pengaturan itu meliputi pengaturan mikropon, kabel, prosesor, dan efek suara. Suara dalam film dapat dipahami sebagai seluruh suara yang keluar dari gambar, yakni dialog, musik, dan efek suara (Pratista, 2008). Selanjutnya pada tahap pasca produksi adalah editing, yaitu proses mengorganisir, reviewing, memilih, dan menyusun gambar dan suara hasil rekaman produksi. Editing menghasilkan tayangan gambar yang padu dan cerita yang penuh makna sesuai apa yang telah direncanakan sebelumnya yaitu untuk menghibur, menginformasikan, memberi inspirasi dan lainnya. Dapat dilihat pada Gambar 8.

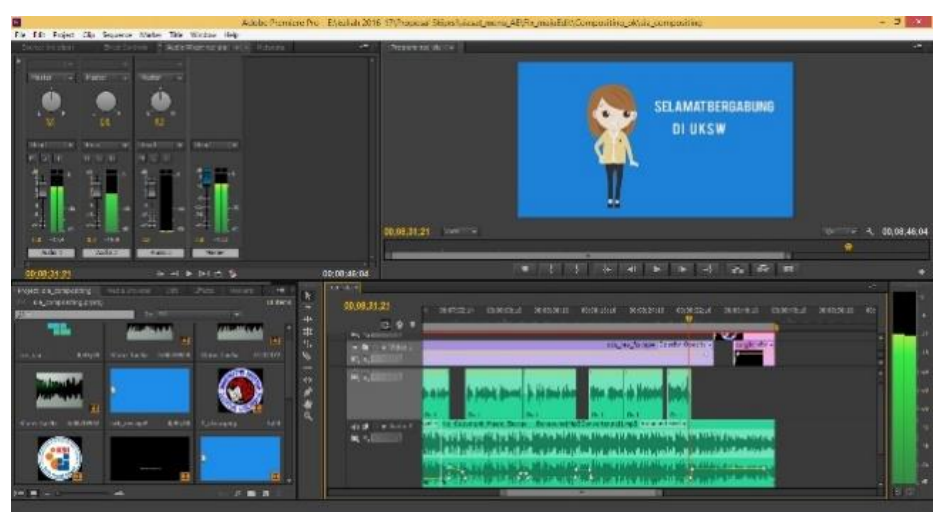

\section{Gambar 8. Editing}

Tahap keempat adalah pengujian. Sebelum diuji kepada MABA, terlebih dahulu video sosialisasi SIASAT diujikan kepada manager Biro Administrasi Akademik (BAA) periode 2017-2021 dan Kepala Bagian Administrasi dan Regristrasi Akademik (BARA) 
periode 2017-2021 sebagai penyelenggara sistem akademik UKSW dan penyelenggara sosialisasi SIASAT pada agenda OMB 2018/2019. Dari hasil wawancara diperoleh hasil bahwa video infografis sosilaisasi SIASAT memiliki komponen konten cukup lengkap dan alurnya cukup jelas. Desain dan pewarnaan tiap komponen sudah baik dan menarik. Selain itu penggunaan audio untuk backsound sudah tepat sehingga mendukung pengisi suara menjadi cukup jelas dan enak didengar, sehingga akan memudahkan BAA dan BARA menyampaikan sosialisasi SIASAT kepada MABA dalam agenda OMB yang akan datang.

Setelah itu, tahap pengujian dilakukan kepada target penelitian. Pengujian pertama kepada mahasiswa UKSW yang sudah menggunakan SIASAT, dilakukan melalui wawancara terhadap beberapa mahasiswa dari berbagai fakultas, diperoleh hasil bahwa video infografis sosialisasi SIASAT mudah dimengerti dan bermanfaat sehingga membuat mereka menjadi lebih paham dalam menggunakan SIASAT, serta pengunaan ilustrasi dan pengisi suara tidak membosankan untuk dinikmati sampai video selesai ditayangkan. Kemudian pengujian kedua dilakukan dengan siswa kelas XI SMA Laboratorium Kristen Satya Wacana dan SMK Kristen Salatiga, diperoleh hasil bahwa mereka merasa diajak berperan aktif menjadi mahasiswa baru yang dibantu fasilitator dalam mengetahui informasi akademik UKSW melalui video infografis yang menarik dan jelas animasinya sehingga informasinya mudah diterima. Kemudian pengujian ketiga, dilakukan melalui open forum mahasiswa yang diselenggarakan FKIP-PGSD dengan peserta open forum tersebut adalah MABA tahun 2017/2018, mahasiswa angkatan 2016/2017 dan mahasiswa angkatan 2015/2016. Melalui video infografis sosialisasi SIASAT diperoleh hasil wawancara bahwa sebagian besar mahasiswa menjadi cukup jelas dan semakin paham dengan informasi yang ditayangkan mengenai administrasi akademik UKSW dan prosedur dalam melakukan SIASAT, yang sementara ini mereka hanya mengikuti saja prosedur tersebut tanpa memahami langkah yang sebenarnya mereka lakukan. Maka dapat disimpulkan bahwa media sosialisasi sistem informasi akademik satya wacana berbasis video infografis layak dan dapat digunakan untuk menyampaikan informasi akademik satya wacana (SIASAT). Hal tersebut disebabkan oleh beberapa faktor yaitu sebagai berikut.

Pertama, media sosialisasi sistem informasi akademik satya wacana berbasis video infografis layak dan dapat digunakan untuk menyampaikan informasi akademik satya wacana (SIASAT) karena video informasi yang dikembangkan menarik. Desain dan pewarnaan yang digunakan pada video grafis yang dikembangkan menarik dan memperhatikan desain pesan. Penggunaan audio untuk backsound sudah tepat sehingga mendukung pengisi suara menjadi cukup jelas dan enak didengar. Latar belakang berwarna biru cerah karena warna biru dapat memberikan kesan dinamis dan dapat diandalkan berfungsi di garis belakang (background) sebagai subjek untuk mendukung objek utama. Media video menjadi efektif karena berisi bahan yang telah disusun dalam format sajian yang dilengkapi dengan unsur audio (Mahadewi, 2012). Selain itu video kelebihan video yaitu mampu menyajikan unsur warna, bunyi, gerakan, dan suatu proses dengan jelas, dapat mengkoordinasikan penggunaan berbagai media yang lain dengan baik seperti film, foto, slide, dan gambar, sehingga dapat menarik perhatian, memperjelas makna (Kurniawan, Agung, \& Tegeh, 2017).

Kedua, media sosialisasi sistem informasi akademik satya wacana berbasis video infografis layak dan dapat digunakan untuk menyampaikan informasi akademik satya wacana (SIASAT) karena lebih mudah dipahami oleh mahasiswa. Kelebihan video animasi dapat digunakan sebagai media komunikasi, seperti media informasi, hiburan, persuasi dan pendidikan dalam berbagai bentuknya (Aziz, 2019). Konten yang disajikan pada video grafis yang dikembangkan lengkap dan alurnya jelas sehingga memudahkan mahasiswa untuk memahaminya. Perancangan konten menggunakan gaya flat desain agar konten yang ditampilkan sederhana dan menarik, sehingga lebih efektif dan mengurangi fokus terhadap bentuk dan ikon yang berlebihan. Penelitian yang dilakukan oleh (Dwipayana, 2013) 
menyatakan bahwa melalui media video lebih mudah meningkatkan pemahaman anak. Media video animasi memiliki kelebihan yaitu dapat menjadi media komunikasi audio visual dalam mengembangkan symbol visual dalam menyampaikan suatu informasi (Aziz, 2019).

Penelitian yang dilakukan oleh Yudha, Pudjawan, \& Tegeh (2017) menyatakan bahwa media video dapat membantu siswa dalam memahami materi dengan mudah. Penelitian yang dilakukan oleh Massi (2018) menyatakan bahwa media video sangat efektif untuk meningkatkan pengetahuan serta pemahaman. Penelitian yang dilakukan oleh Fadhli (2015) juga menyatakan bahwa media video dapat meningkatkan pemahaman siswa serta dapat meningkatkan prestasi siswa

\section{Conclusion}

Berdasarkan hasil penelitian yang dilakukan disimpulkan bahwa media sosialisasi menggunakan video infografis dapat digunakan sebagai sarana yang informatif dalam menyampaikan sistem yang ada di dalam suatu instansi dalam hal ini di UKSW yang dapat digunakan untuk sosialisasi sistem administrasi akademik kepada calon dan mahasiswa baru serta lingkungan civitas kampus.

\section{References}

Al-Kariimah, \& Rosiana. (2017). Hubungan Antara Dukungan Sosial Dengan Penyesuaian $\begin{array}{lllll}\text { Diri Di Perguruan Tinggi. Prosiding } & \text { Psikologi, }\end{array}$ https://doi.org/http://dx.doi.org/10.29313/.v0i0.6002

Anwar, \& Nurkidam. (2018). Paradigma Sosialisasi Dan Kontribusinya Terhadap Pengembangan Jiwa Beragama Anak. Komunida: Media Komunikasi Dan Dakwah, 8(2). https://doi.org/https://doi.org/10.35905/komunida.v8i2.631

Arifuddin, Suwatra, \& Mahadewi. (2020). Pengembangan Konten E-learning Berorientasi Pendidikan Karakter Pada Mata Pelajaran Seni Budaya. Jurnal Edutech Undiksha, 8(2). https://doi.org/http://dx.doi.org/10.23887/jeu.v8i2.28942

Arimbawa, Agustini, \& Santyadiputra. (2018). Pengembangan Sop Berbasis Infografis JenisJenis Penelitian Untuk Perkuliahan Metodologi Penelitian Pendidikan. Jurnal Pendidikan Teknologi Dan Kejuruan, 15(1). https://doi.org/http://dx.doi.org/10.23887/jptk-undiksha.v15i1.12288

Arsyad, A. (2014). MediaPembelajaran. Jakarta: PT Raja Grafindo Persada.

Aziz, Z. (2019). Fluxus Animasi dan Komunikasi di Era Media Baru Digital. Channel Jurnal Komunikasi, 7(1), 49-58. https://doi.org/http://dx.doi.org/10.12928/channel.v7i1.13017

Cahyadi, Budiardjo, \& Dewanto. (2016). Perancangan Iklan Kampanye Trunk And Feeder Melalui Infografis Sebagai Upaya Pengenalan Transportasi Baru Di Kota Surabaya. Jurnal Art Nouveau, 5(1).

Damsar. (2011). Pengantar Sosiologi Pendidikan. Jakarta: Penerbit Kencana Prena Media Group.

Daryanto. (2011). Media pembelajaran. Jakarta: PT Raja GrafindoPersada.

Dwipayana, I. K. (2013). Kemampuan Siswa Dalam Pelajaran Biologi Dengan Menggunakan Media Pembelajaran Berbasis Video Animasi Pada Siswa Kelas VII DI SMP Negeri 2 Singaraja Tahun Pelajaran 2011/2012. Jurnal Edutech Undiksha, 1(1). https://doi.org/http://dx.doi.org/10.23887/jeu.v1i1.360 
Fadhli, M. (2015). Pengembangan Media Pembelajaran Berbasis Video Kelas IV Sekolah Dasar. Jurnal Dimensi Pendidikan Dan Pembelajaran, 3(1), 24-29. https://doi.org/http://dx.doi.org/10.24269/dpp.v3i1.157

Hadi, I. A. (2017). Pentingnya Pengenalan Tentang Perbedaan Individu Anak Dalam Efektifitas Pendidikan. INSPIRASI: Jurnal Kajian Dan Penelitian Pendidikan Islam, 1(1). Retrieved from https://ejournal.undaris.ac.id/index.php/inspirasi/article/view/5

Idrus, A. (2014). Pemanfaatan Teknologi Informasi Dan Komunikasi Dalam Layanan Administrasi Akademik Terhadap Peningkatan Kinerja Di SMA Negeri Kota Jambi. Tekno-Pedagogi, 4(2). Retrieved from https://onlinejournal.unja.ac.id/pedagogi/article/view/2290

Iflah, \& Listyasari. (2013). Gambaran Penyesuaian Diri Mahasiswa Baru. JPPP: Jurnal $\begin{array}{llll}\text { Penelitian Dan Pengukuran } & \text { Psikologi, }\end{array}$ https://doi.org/https://doi.org/10.21009/JPPP.021.05

Indrayani, E. (2011). Pengelolaan Sistem Informasi Akademik Perguruan Tinggi Berbasis Teknologi Informasi dan Komunikasi (TIK). Jurnal Penelitian Pendidikan, 12(1). Retrieved from http://jurnal.upi.edu/penelitian-pendidikan/view/437/pengelolaansistem-informasi-akademik--perguruan-tinggi-berbasis-teknologi--informasi--dankomunikasi--tik-.html

Iskandar, \& Tumimomor. (2017). Perancangan Media Sosialisasi Tanggap Bencana Kabupaten Semarang Berbasis Animasi 2D. FSD UNM, 4(2). https://doi.org/https://doi.org/10.26858/tanra.v4i2.4386. FSD UNM

Kurniawan, Agung, \& Tegeh. (2017). Pengembangan Video Pembelajaran Teknik Dasar Sepak Bola Dengan Konsep Quantum Learning. Jurnal Edutech Undiksha, 5(2), 179188. https://doi.org/http://dx.doi.org/10.23887/jeu.v5i2.20374

Lankow, Ritchie, \& Crooks, R. (2014). Infografis: Kedahsyatan Cara Bercerita Visual. Jakarta: Gramedia Pustaka Utama.

Mahadewi, D. (2012). Buku Ajar: Media Video Pembelajaran (E-Book). Singaraja: Undiksha.

Massi. (2018). Efektifitas Pemberian Edukasi Dengan Metode Video dan Focus Group Discussion (Fgd) Terhadap Tingkat Pengetahuan Pasien Dm Tipe 2 Di Klinikdiabetes Kimia Farma Husada Manado. Journal Keperawatan (e-Kep), 6(1), 1-6.

Munir. (2013). Multimedia Konsep \& Aplikasi dalam Pendidikan. Bandung: Alfabeta.

Pratista, H. (2008). Memahami Film. Yogyakarta: Homerian Pustaka.

Sarwono, J. (2007). Metode Riset untuk Desain Komunikasi Visual. Yogyakarta: CV. Andi Offset.

Siddiq, Sudarma, \& Simamora. (2020). Pengembangan Animasi Dua Dimensi Pada Pembelajaran Tematik Untuk Siswa Kelas III Sekolah Dasar. Jurnal Edutech Undiksha, 8(2), 49-63. Retrieved from https://ejournal.undiksha.ac.id/index.php/JEU/article/view/28928

Suhardi, Sunarti, S. (2009). Sosiologi 1. Jakarta: Departemen Pendidikan Nasional.

Suyanto, M. A. K. (2006). Merancang Film Kartun Kelas Dunia. Yogyakarta: Andi Offset. 
Syaripul, \& Bachtiar. (2016). Visualisasi Data Interaktif Data Terbuka Pemerintah Provinsi Dki Jakarta: Topik Ekonomi Dan Keuangan Daerah. Jurnal Sistem Informasi (Journal of Information System), 12(2). https://doi.org/https://doi.org/10.21609/jsi.v12i2.481

Tegeh, Simamora, \& Dwipayana. (2019). Pengembangan Media Video Pembelajaran Dengan Model Pengembangan 4D Pada Mata Pelajaran Agama Hindu. Mimbar Ilmu Undiksha, 24(2), 158-166. Retrieved from https://ejournal.undiksha.ac.id/index.php/MI/article/view/21262/13262

Tufte, E. R. (1990). Envisioning Information. Cheshire: Graphics Press.

Wicandra, O. B. (2001). Memahami Wacana Infografis: Sebuah Kajian Semiotik dengan Kasus Infografis pada Seksi Deteksi Harian Jawa Pos Edisi Bulan Februari-Bulan Oktober. Institut Seni Indonesia, Yogyakarta.

Widagdo, M. B., \& Gora, W. (2007). Bikin Film Indie Itu Mudah. Yogyakarta: Penerbit Andi.

Yudha, Pudjawan, \& Tegeh. (2017). Pengembangan Video Matembang Sekar Alit Berbasis Model Direct Instruction DI SMP Negeri 5 SINGARAJA. Jurnal Edutech Undiksha, 5(1), 19-27. https://doi.org/http://dx.doi.org/10.23887/jeu.v5i1.20198

Yuliani, Antara, \& Magta. (2017). Pengaruh Video Pembelajaran Terhadap Kemampuan Berhitung Permulaan Anak Kelompok B Di Taman Kanak-Kanak. Jurnal Pendidikan Anak Usia Undiksha, 5(1), 96-106. https://doi.org/http://dx.doi.org/10.23887/paud.v5i1.11309.

Yusnia, Y. (2019). Penggunaan Media Video Scribe Dalam Pembelajaran Literasi Sains Untuk Mahasiswa PGPAUD. Cakrawala Dini: Jurnal Pendidikan Anak Usia Dini, 10(1), 71-75. 